\title{
ePortfolios Beyond Pre-Service Teacher Education: a New Dawn?
}

Abstract

The context of this paper is the final phase of a longitudinal action research project investigating whether an ePortfolio, created as a pre-service teacher to evidence a digital story of developing professional identity, could transition into employability, ie the first year as a newly qualified teacher. Thus this paper focuses on a new area of ePortfolio related research in teacher education; the transition from university into employment. The research findings indicate a changing purpose of the ePortfolio from training to the workplace $_{2}$ along with an increasing strength of ownership as part of the transition ${ }_{2}$ and empowerment in becoming a teacher. Key outcomes are discussed and arguments presented for an ePortfolio to support professional development from university to employment.

Keywords: ePortfolio; technology; secondary; pre-service teachers; newly qualified teachers; continuing professional development; employablity.

\section{Introduction}

This paper presents the findings of a research project focussing on ePortfolios in pre-service teacher education from university into employment and is therefore of interest to teacher educators both in the United Kingdom (UK) and internationally. This paper thus-builds on existing research into ePortfolios in pre-service teacher education and explores a new area of development by examining how and if the ePortfolio, created as a pre-service teacher, can be extended into the NQT year. The research draws on key theories of identity, self-regulation leading to self-efficacy, and situated learning; these are discussed in more detail later in the paper. The project was part funded by the Training Development Agency, UK.

The context is the final phase of a longitudinal action research project spanning four years at Nottingham Trent University (NTU), United Kingdom (UK), focussing on the evaluation of ePortfolios for pre-service teachers to present evidence of their digital journey to becoming a teacher. This final phase aimed to identify whether the e-Portfolio, developed as a pre-service teacher, could create a space where a newly qualified teacher (NQT), working in a 'situated' context could reflect on teaching and plan targets for future action.

Two key aims were identified for this phase: to pilot the use of ePortfolios beyond teacher training, initially into the NQT year; and to identify if whether an ePortfolio tool 
could continue to support the professional development for NQTs during their continuing teaching career. The focus for this phase was NQTs employed in the secondary sector (11-18 years) who had completed either a Post-Graduate Certificate in Education (PGCE) ${ }^{1}$ or a Graduate Teacher Programme ${ }^{2}$ (GTP) in the previous year within the School of Education at NTU. This a n

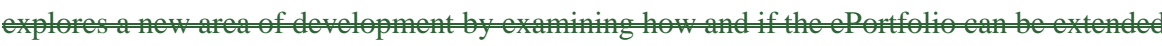
inte the NQT year. The research draws on key theories: identity, self-regulation leading to self-efficacy, and situated learning; these are discussed in more detail later in the paper. The projer part funded by the Training Development Agency, UK.

A brief overview of the four year project moves from the early stage of identifying key requirements for an ePortfolio tool working with pre-service teachers and academic tutors. In the first year of the project a group of PGCE pre-service teachers $(n=17)$ evaluated two e-portfolio toolsdigital platforms over the course of one year: one closed, that is integraltoel was part of to the University's Virtual Learning Environment (VLE); the second was-open using open-source software (Moodle $($ ), which, while not marketed as an epertfolio tool was-set up to provide ePortfolio functionality. This phase of the project identified the open digital platform-source software as meeting the needs of the pre-service teacher more than the university VLE dedicated e portfolio tool. This was-mainly due to a lack of interoperability and diffieulties in providingclosed access to external persons externat to the university VLE based ePortfolio tool (such as school-based mentors). In Year two of the project pre-service teachers on the PGCE secondary phase course $(n=32)$ successfully piloted the open-source platform e-Portfolio throughout their school-based experience. In Year 3 of the project the e-portfolio was made available to all primary and secondary preservice teachers across a range of programmes $(n=100+)$ : BA (Hons) Primary Education, PGCE Primary, PGCE Secondary, GTP (secondary and primary). At the end of Year 3 a full evaluation of the ePortfolio took place using focus groups and questionnaires involving both pre-service teachers, tutors and school-based mentors. The results indicated that the opensource-platform ePortfolio was providing provided a robust system that met the needs of the pre-service teachers, that is, a place to build authentic, multi-modal evidence of professional identity where tacit, authentic knowledge could be exemplified.

Use of ePortfolios in Pre-Service Teaching

Background

Much has been written about portfolios and ePortfolios in teacher education (Loughran and Corrigan, 1995; Wright, Stallworth and Ray, 2002; Lorenzo and Ittleson, 2005; Park and Lim, 2006; Zellers and Mudrey, 2007; Hartmann and Calandra, 2007; Young, 2008; Imhof

${ }^{1}$ The PGCE is a one-year pre-service teaching course at M level (second level) with 24 weeks spent in two different secondary schools; the remainder of the course is spentin university.

${ }^{2}$ GTP is a one-year pre-service teaching course based in a school with days spent in university. 
and Picard, 2009; Jones, 2010; Joyes, Gray and Hartnell-Young, 2010; Chatham-Carpenter, Seawel and Raschig, 2010; Meyer et al., 2010) and relating to Higher Education beyond preservice teacher training education (Lankes, 1995; Mason, Pegler and Weller, 2004; Challis, 2008; Bolliger and Shepherd, 2010; Vernazza et al., 2011). However, a literature search found no evidence of research based on the continuation of an ePortfolio from university into employment within the context of teacher education, the focus of this paper. Theis following section examines research into ePortfolios in teacher education.

\section{Professional Development}

Developments with technology enable ePortfolios to be owned by individuals who can share artefacts, critical reflections (Kolb, 1984; Hatton and Smith, 1995 Moon 1999; Jay and Johnson, 2002; Roberts, 2009; Boulton and Hramiak, 2012) and so onprofessional development for 'collective learning and knowledge sharing' (Lorenzo and Ittleson, 2005, p. 4). Others such as Mason, Pegler and Weller (2004) acknowledge the adaptation from the traditional 'portfolio' into the electronic domain. The result is normally a digital story of the pre-service teacher's journey, charting professional development, leading to professional identity and the construction of individual educational philosophy (Avraamidou and ZembalSaul, 2003).

\section{Purpose and Genre}

Researchers have identified varied genres and purposes of ePortfolios in teacher education. For example Mason, Pegler and Weller (2004, p. 717) identified different-purposes of the ePortfolio such as 'developmental', 'presentation', and 'assessment' focussed. Others have made-suggested similar purposes such as Roberts $(2009$, p. 638) who identified a 'dossier portfolio', a 'training portfolio', a 'reflective portfolio', and a 'personal development portfolio'. D' Aoust (1992, in Falchikov, 2005 p. 17) suggested that there are three different types-genres of portfolio: an exemplary portfolio where students place their best pieces of work; a process portfolio which demonstrates the developmental process of the student's learning; and a combined portfolio which contains examples of both exemplary work and developmental work. Others have made suggested similar purpeses such as Roberts ( 2009 , p.

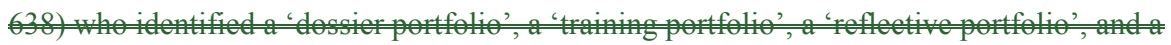
"persenal development pentfolio?. Earlier phases of this research project suggested that a further type, providing evidence in support of professional competencies, emerged. The final phase of this research, reported in this paper, suggests a changing purpose of the ePortfolio once qualified teachers, reflecting the changing needs of the 'owner' as their role changes and they become more goal driven as qualified teachers (Conway, 2001).

\section{Self rReflection and Identity}

Discourses in teacher education reflect the complexity of the context of teaching and the need to develop reflective practice critically, linking theory to practice, developed within preservice training and continued throughout the teachers' career (Yaffe, 2010). For the

Formatted: Font: Italic

Formatted: Indent: First line: $0 \mathrm{~cm}$ 
ePortfolio to be integrated into the NQT year it needed to provide a sustainable place for evidence linking to individual goals. Part of the development of professional identity for preservice teachers is becoming reflective practitioners, who are able to identify their own developmental needs (Loughran, 2002).

Some researchers see the development of reflective practice as 'inbuilt in the formation of an ePortfolio' (Zellers and Mudrey, 2007, p. 420). We would argue that becoming a reflective practitioner is learnt and requires practice drawing on Jones' (2010, p. 593) definition of reflection as 'a process of critically examining one's past and present practice as a means of building one's knowledge and understanding in order to improve practice'. Stenberg (2010, p. 334-335) indicates the close relationship between self-reflection and self-identity based on 'values, beliefs and understandings', and views reflection as 'a meaning-making process' towards professional identity based on the 'teacher's personal practical theory'.

This notion of linking self-reflection and self-identity is, in our opinion, key to ePortfolio development for pre-service teachers. E-Portfolios provide a space where preservice teachers can reflect 'on' and 'in' practice by making links between evidence in their ePortfolio and the development of their professional identity (Schon, 1983) as part of a community of teachers. Beauchamp and Thomas (2010) discuss the close link between reflection and identity development and the ways in which reflection includes consideration of beliefs and values which in turn will develop their educational philosophy, fundamental to the process of becoming a teacher. Educators using multi-modal technologies for reflections, such as video-diaries (Stenberg, 2010), indicate that these sit well within ePortfolios and provide an alternative method to more traditional formats of reflective practice.

\section{Assessment and Feedback.}

At NTU the ePortfolio alse has a role in the assessment of pre-service teachers and an opportunity for both formative and summative assessment. This is a key strength in assessment opportunities provided by the ePortfolio, which is recognised by Zellers and Mudrey (2007, p. 412) who found that formative feedback was part of the 'whole process' and an integral part of the development of the ePortfolio. Young (2008) views the ePortfolio as providing flexibility in formative feedback while Granberg (2010) also found the blend of formative and summative feedback as part of the ePortfolio building process was a benefit rather than problematic.

Access.

In addition pPre-service teachers and NQTs may be supervised by a range of people involved $+$ in their professional development, all of whom require access to the range of evidence within the ePortfolio (Avraamidou and Zembal-Saul, 2003). With phase one of this longitudinal research project, referred to earlier, access had arisen as a key aspect and was one of the main reasons for the pre-service teachers involved in the evaluation phase of the project to reject the closed ePortfolio toel-platformwithin the University's VLE. Being able to give access to 
colleagues, peers, mentors and tutors simply and easily to all, or specific artefacts, has continued to be key to the success of the ePortfolio reflected at NTU.

Thus previous research by the author and others indicates broad agreement on the purposes, processes and benefits of ePortfolios in pre-service teacher education; to provide a space to build authentic, multi-modal evidence of professional identity where tacit, authentic knowledge can be exemplified, critical reflection can be developed and linked to assessment and developing evidence can be shared with others. This paper extends this body of knowledge furtherby identifying key areas for consideration of an ePortfolio as part of the transition from university into employment within the context of teacher education. The following section identifies key theories relating to this research; professional identity, selfregulation leading to self-efficacy and situated learning.

\section{Theoretical Framework}

In this section key theories are identified which relate to the research; professional identity, self-regulation leading to self-efficacy and situated learning.

Central to the use of ePortfolios within this research is Bandura's (1982; 2001) social cognitive theory of self-regulation leading to self-efficacy. Bandura particularly focussed on personal agency impacting on motivation, self-monitoring, time management and planning, goal setting, self evaluation and action; these formed key areas for the data collection. Selfregulation when using ePortfolios enables pre-service teachers to engage in complex meaningful evidencing of their professional development (Blackburn and Hakel in Jafari and Kaufman, 2006; Meyer et al. (2010). Strivens et al., (2009) report that self-regulation is important in ePortfolio development, ensuring a consistent development of artefacts, including reflections. Wade, Abrami and Sclater (2008) break this into metacognitive selfregulation, physical and social environment management, time management and effort regulation relating to achieving goals. Abrami et al. (2009) suggest three cyclical phases of self-regulation: 'forethought', that is, planning and goal setting; 'performance', that is, self observation; and 'self-reflection'.

In developing the use of ePortfolios in teacher education a subjectivist stance is taken 'based on the belief that learning is complex, situated, and individual and must be judged by experts directly involved in teaching and learning' (Strudler and Wetzel, 2011, p. 162).

\section{Methods}

This final phase of the research project lasted for a year, May 2010-May 2011. The purpose of starting the phase in May was so that contact could be established with a range of preservice teachers at the University NTU who were considering using an e-Portfolio as a NQT. 
An-requestrequest invitation for volunteers to take part in the research was sent out to all preteachers, irrespective of whether they had used an ePortfolio during their pre-service training The intention of the invitation to such a wide group was to ensure no student felt excluded and to reflect informal conversations with some students who had not taken the opportunity to engage with the ePortfolio during their pre-service training and intendinged to do so as an An initial briefing was held with velunteer those responding to the invitation $(n=25)$ prepurpose of the project, their involvement in terms of time and the methods that would be used to collect data. At this briefing ethical considerations were discussed, in particular the anonymisation of any individual findings or quotations and the right to withdraw from the research at any time. Respondents were asked to give their consent to being part of the project. Seale and Abbott's (2007) discussion of methodological issues in researching online representations, including ePortfolios, informed the ethics of this study. Those who remained at the end of the briefing to complete the ethical clearance process were selected $(n=8)$.

Those who attended but did not take part in the project $(n=17)$ listed reasons as concern with the NQT year and time commitments, lack of confidence in the IET infrastructure at the they would be working at, or were still looking for employment; this reflects research by Bingimlas (2009).

The final group of participants comprised seven pre-service teachers from the PGCE secondary course, and one pre-service from the GTP secondary course. Within the group there was an age range from 22-45; there was an equal balance of male and female respondents. The respondents were from mixed disciplines with a minimum first degree classification of 2.2. The geographical area in terms of schools in which the participants were working as NQTs was from the East Midlands to the south of England (London).

The research represents a small scale case study (Bogdan \& Biklen, 1998), while action research provided the methodological framework based on the model presented by Carr and Kemmis (1986) and developed by Reason and Bradbury (2008).

The research was collaborative and involved working with NQTs and key staff in schools to find practical solutions to using an ePortfolio during the NQT year, and, potentially, during their continuing career.

Data for this phase was collected using both qualitative and quantitative methods:

- Interviews:

○ interviews with each of the pre-service teachers took place twice using a semistructured approach. The first interview was carried out while pre-service teachers were still training. The second interview was carried out during the second term of their NQT year. The interviews contained questions relating to use of the ePortfolio during their pre-service training year and their NQT year, including their motivations, drawing on Bandura's (1982) theory of selfefficacy. Responses enabled the researchers to identify key themes drawing on Wenger's (1998) theory of professional identity; 
- interviews were also held with key academic staff $(n=5)$ in the School of Education at Nottingham Trent University.

- Questionnaire: an electronic questionnaire was sent to head teachers of schools within NTU's Partnership, across the East Midlands, UK. An in-University electronic questionnaire tool was used for this purpose. A total of 103 head teachers responded to the questionnaire. The focus-purpose of the questionnaire was ento ascertain whether head teachers visioned a future for ePortfolios as a central part of continuing professional identity for teachers. The view of head teachers was seen by the authors to be important to the project as research by others indicated a lack of support with new technologies by senior school managers could impede the development of ePortfolios for professional development (Hammond, 2009; Bingimlas, 2009; Boulton and Hramiak, 2012).

- Observations: throughout the project the researcher had access to the e-Portfolios of those taking part in the project. This enabled observation of artefacts and reflections that were uploaded into ePortfolios which were then analysed into key themes.

- Data was kept on how often, when, and type of artefacts uploaded by the participants. This data was analysed to inform the research and is discussed in the following section.

Once the interviews had been transcribed and data collected it was coded to identify key themes which are discussed in the next section. Recurrent themes that emerged were tracked by listing how often they appeared in the data. The analysis of the data focussed on the key aims of the research: to pilot the use of are ePortfolios beyond teacher training appropriate; and to identify if an ePortfolio could continue to support the professional development for NQTs during their continuing teaching career.

\section{Findings and Discussion}

As discussed in the previous section the data was coded to identify key aspects which were then grouped to form themes. The main themes of reflection, professional identity, selfregulation, assessment and feedback, collaboration, purpose and ownership were identified and are each discussed below:

\section{Reflection}

The development of reflective practice for teachers was identified earlier as a key component of ePortfolios drawing on Schon (1983), Kolb (2984), Loughran (2002), Yaffe (2010), Jones (2010), and Stenberg (2010). Observations of the completed ePortfolios during each phase of the research indicated that the ePortfolio provided a place for recording reflections and developing a level of deep reflective practice. This was seen as a key part of the ePortfolio, continuing into the NQT year, by all respondents.

Encouragement of sharing reflections to provide peer support to enhance student learning and gain multiple perspectives on reflections is becoming more prevalent in higher 
education (Alterio, 2004; Rocco, 2010; Boulton and Hramiak, 2012). While reflection was that the ePortfolio tool does provide an opportunity for sharing artefacts, reflections and so and would be of benefit to pre-service teachers in gaining multi-perspectives on reflections.

The data collected indicated that as a pre-service teacher multiple reflections formed part of their ePortfolio (approximately twenty five percent of their ePortfolio). Observations of reflections indicate that respondents made links between theory and practice during their pre-service course with some developing a deep level of critical reflection (Dewey, 1933) drawing on pedagogical literature and making links to their practice. This supports findings by Lazarus and Olivero (2009). The ePortfolio thus provided an opportunity to contextualise reflections and 'identify those areas where they might personally improve, highlighting strengths, weaknesses and identifying gaps for further improvement' (Roberts, 2009, p. 636).

However, once qualified teachers, and working as NQTs their reflections formed a minimal part of their ePortfolio (less than five per cent). A thematic analysis of content indicated a change in reflections in the respondents' ePortfolio once they were NQTs in terms of making links between theory and practice; they drew less on literature and more on their own experiences developing their reflections to a deeper level. This suggests that NQTs feel more confident in the development of their pedagogical philosophy and professional identity. This finding is reflected by Avraamidou and Zembal-Saul (2003) and Yaffe (2010, p. 381) who identifies different stages of reflection among NQTs: 'the reflective monologue; the reflective dialogue; and the meta-reflection stage'. The evidence from the project reported in this paper would suggest that the participants were at stage 2 (the reflective dialogue) during their pre-service training, and moving to stage 3 towards the end of their pre-service training and continuing into their NQT experience.

\section{Professional Identity}

The ePortfolio is mainly used within teacher education to build multi-modal evidence of authentic professional identity where tacit knowledge can be exemplified to demonstrate competence aligned to professional standards as set out by the Teaching Agency (TA). As part of the process developing professional identity within a professional community emerges; Wenger (1998) emphasises the importance of identity in professional practice-

As stated earlier the number of artefacts uploaded to the e-Portfolio of respondents during the pre-service teaching course was significantly higher than during the NQT experience. When asked in the second interview about the number of artefacts presented respondents commented that in their NQT year there was less emphasis on producing evidence for their Teaching Standards, which resulted in them uploading fewer artefacts than in their pre-service training. This could arguably be interpreted that the respondents, when pre-service teachers saw their e-Portfolio as a tool for providing evidence against standards, rather than a place to develop their own professional identity as a teacher. The changing emphasis on the ePortfolio for evidencing standards was of much less significance once an NQT, even though Teaching Agency standards still had to be achieved in the NQT year. Respondent F commented 
'at school evidence of meeting professional standards is less about providing evidence and more about verbally discussing our progress.'

Thus suggesting that the respondent viewed the e-Portfolio as an assessment tool rather than as a repository for authentic evidence for evidencing professional identity, career progression, and so on. However, respondent $\mathrm{C}$ stated

'the e-Portfolio inspires me to record my development, I see it as much more than a place for storing artefacts and providing evidence for assessment'.

These differing views reflect that ePortfolios should be owned by individuals and used by them for their own purposes. However, there is a dichotomy identified by Strudler and Wetzel (2011) that ePortfolios should have a clear purpose, that is, either for the development of professional identity based on subjectivist philosophy or to demonstrate how they have met teaching standards for the purpose of assessment based on an objectivist philosophy. Increasingly examples are being given of using ePortfolios to evidence professional identity (Beijaard, Verloop and Vermunt, 2000; Cambridge, 2008; Barrett and Garrett, 2009); 'the more self-knowledge a teacher has, the more appropriate are his or her decisions to paving the way to better teaching' (Stenberg, 2010, p. 1). It may therefore be that in trying to provide an easily accessible electronic 'place' for digital artefacts articulating experiences, achievements and learning that reflect the development of professional identity, to then add an additional layer of assessment may simply not be appropriate and may restrict the continued development of the ePortfolio once qualified. Thus the view of Roberts (2009) and D'Aoust (1992, in Falchikov, 2005), discussed earlier may better reflect the purposes of an ePortfolio for qualified teachers and reflect the use of ePortfolios across Europe where assessment of competencies differs to the UK.

\section{Self-regulation}

As discussed earlier Bandura's $(1991,2001)$ theory of self- regulation leading to self-efficacy provided a theoretical framework for this research with key aspects forming part of the second interview for the NQTs-as indicated in Table 1 . The respondents were asked to rate themselves on a scale of 1-5, with 1 being low and 5 being high, to identify which aspects of self-efficacy impacted on their-usagee of their ePortfolio. The results indicate that as preservice teachers motivation scored highly with an average of 4.8 , but as NQTs their motivation had reduced slightly to an average of 3.9, while goal-setting, seen as less of an impact as a pre-service teacher with an average of 2.8 , had risen to an average of 4.5 as NQTs. This links to a key theme, absent from the analysis of interviews as pre-service teachers, but occurring in each interview as NQTs, of continuing professional development (CPD). NQTs commented that their Continuing Education Development Profile (CEDP), completed at the end of their pre-service course, setting out key goals for their CPD as part of the transition into employment NQT, had been included in their ePortfolio. Respondents reported that this focussed their self-evaluation and goal setting towards specific CPD developmental priorities which would be equally important to pre-services teachers across Europe. 
Respondents also commented that self-monitoring their ePortfolio had dropped as an NQT which would align to the reduced activity in uploading artefacts and the number of artefacts included in any one month, as compared to when they were pre-service teachers. Analysis of both interviews indicates that this activity was in part due to a change in their usage of the ePortfolio, that is, less focussed on evidencing standards and more focussed on professional identity and professional development. 'People form beliefs about what they can do, they anticipate the likely consequences of prospective actions, they set goals for themselves, and they otherwise plan courses of action that are likely to produce desired outcomes' (Bandura, 1991, p. 248).

\begin{tabular}{|c|c|c|}
\hline Areas of Self-Efficacy & $\begin{array}{l}\text { Average as pre- } \\
\text { service teacher }\end{array}$ & $\begin{array}{l}\text { Average as } \\
\text { NQT }\end{array}$ \\
\hline Motivation & 4.8 & 3.9 \\
\hline Self-monitoring & 4 & 3.2 \\
\hline Time-planning and management & 4 & 3.9 \\
\hline Goal setting & 2.8 & 4.5 \\
\hline Self-evaluation & 3.9 & 4.1 \\
\hline $\begin{array}{l}\text { Self-Efficacy - perceptions about one's } \\
\text { capabilities to organize and implement } \\
\text { actions necessary to attain designated } \\
\text { performance of skill for specific tasks } \\
\text { (Bandura, 1991). }\end{array}$ & 4.1 & 4.5 \\
\hline
\end{tabular}

Table 1. Areas of self-efficacy.

Respondents recognised that there was a need to self-regulate the development of their ePortfolio, supporting findings by Wade, Abrami and Sclater (2008) particularly focussing on the need to set goals related to their professional development (Wilson, Wright and Stallworth, 2003; Abrami and Barrett, 2008). There was evidence that goal setting changed from their pre-service evidence to their NQT evidence and became driven by their CEDP action plangoals for to inform professional development which continued into their NQT yearin the transition into employment.

\section{Assessment and Feedback}

The ePortfolio provided a space for communication between the viewer of the evidence and the pre-service teacher, or NQT, thus facilitating formative feedback, as well as providing evidence for summative feedback. Assessment and feedback are identified as an integral part of ePortfolio development (Challis (in Falchikov), 2005; Stevenson (in Jafari and Kaufman), 2006; Young, 2008; Granberg, 2010)._Previous phases of this project had identified the importance of formative feedback on the development of the ePortfolio by pre service 
teachers and was recognised by all respondents as a key benefit of the ePortfolio. This purpose of the ePortfolio, and all made comment on it providing authentic, situated, contextualised evidence for this purpose, suggesting a perception that this was a benefit of the ePortfolio.

However, Dthe data from this research indicated tensions in purpose for the ePortfolio when used for assessment as a pre-service teacher, but once an NQT the strength of ownership increased as the assessment purpose decreased. Wilson, Wright and Stallworth (2003) suggest that using ePortfolios for assessment is 'complex', while Barrett identifies an emotional connection to the portfolio arguing that for a portfolio to reflect authentic voice and digital story telling of developing professional identity through lifelong learning there needs to be a 'balanced assessment that supports deep learning' (2007, p. 441).

Academic staff interviewed as part of the data collection all expressed values of student-centred teacher education, reflecting the findings of Strudler and Wetzel (2011). Each academic interviewee described how the ePortfolio formed part of the assessment during the pre-service training, but acknowledged that this purpose may not be as relevant during the NQT year. NQTs need to provide evidence aligned to TA professional standards to pass their NQT year, so it is interesting that the purpose of assessment during the NQT year was not recognised as such by the academics. This finding is supported by data collected during interviews with NQTs.

\section{Collaboration}

The process of collaboration was identified in interviews with six respondents during their pre-service training year thus indicating that this is seen as an important aspect of the development of the ePortfolio. Social interaction through the portfolio process is viewed as critical by Barrett (2007). The process of formative feedback and support by academic staff has also been commented on above. All respondents commented positively on the feedback from key stakeholders and seven had shared artefacts with their peers, again focussing on collaboration. However, the collaboration was reported as considerably lower as an NQT, and in four cases, was yet to form part of the ePortfolio process. This impacted on the view of the NQTs in terms of continuing with the ePortfolio. For example, respondent F commented

'In my university training we were encouraged to work collaboratively and share artefacts in our ePortfolios. Now I'm qualified that support and encouragement is very sparse and the ePortfolio does not appear to be valued so much'.

This suggests that the use of ePortfolios in schools is not yet widespread and NQTs lack the support of community (Boulton and Hramiak, 2012). However, this does not reflect the view of the head teachers who mainly supported the use of the ePortfolio by qualified teachers; enly four outninety-nine of the one hundred and three respondents felt an ePortfolio was not an appropriate tool for building evidence of professional identify. 


\section{Purpose}

In the first interviews with pre service teachers all respondents were clear about the purpose of the ePortfolio; all respondents discussed assessment, formative feedback on professional development and identity, critical reflection and evidencing teaching standards. However, the second interviews indicated that the purpose was less clear as a NQT with three not able to state a clear purpose. Four of the pre-service teachers stated the purpose as continuing professional development and had each created a new section to their ePortfolio to reflect this. There were fewer comments related to assessment during the NQT year providing further evidence of the changing purpose of the ePortfolio for NQTs.

The questionnaire responses from primary and secondary school head teachers would indicate that while ePortfolios for professional development may be in its infancy it will develop, particularly in terms of teachers' CPD in the future. Thus this could be viewed as a challenge to schools to encourage uptake and usage of ePortfolios (Minocha, 2009) particularly when linked to CPD.

Academic staff perceived that, once the pre-service assessments were completed the ePortfolio would become a repository for examples of best practice. This was borne out by half of the NQTs commenting that they felt less motivated to develop their ePortfolio, finding self-monitoring harder once they had left university. For five of the NQT respondents the lack of purpose was impacting on further development of the ePortfolio. As a pre-service teacher the respondents were clear of the purpose, aligning to Mason, Pegler and Weller's (2004, p. 717) identified purposes of 'developmental', 'presentation', and 'assessment', plus the fourth purpose identified through this research; that required for evidence of achievement of professional teaching competencies. As NQTs the purpose changed from a focus on assessment, to that of identifying goals for professional development.

All of the respondents, both pre-service teachers and academics, made reference to time during each interviews. Some researchers comment on the increase in time involved with ePortfolios. For example Zellers and Mudrey (2007, p. 420) state 'Portfolios involve more work, both for the instructor and for the student', and report increased time for tutors identified in their research. This was reflected in the findings in this research. For example when pre-service teachers focussed on the amount of time it took to upload and organise their artefacts they viewed and saw this as an inhibitor, reflecting the findings of Wilson, Wright and Stallworth (2003). However, the alternative would beof printing off and organising evidence in paper-based folders which previous cohorts in earlier phases of the project had complained took up additional time and did not easily facilitate the use of multi-media in their evidence, nor did they view paper-based portfolios as environmentally friendly.

Academic staff recognised there may be a small increase in time involved in uploading evidence, but all agreed the increased access enabled by the ePortfolio enabled them to provide much richer and more frequent formative feedback. 


\section{Ownership}

Ownership of design and content was not recognised in the first interviews of the preservice teachers, but emerged during the second interviews. The data indicated that preservice teachers are more engaged in content and less engaged with ownership of the ePortfolio. The data from the second interviews indicated that this changed when they became NQTs with ownership being much more important. This reflects findings by Strudler and Wetzel (2011). Providing thepre-service teachers with a structure that enabled them to evidence their professional teaching standards proved to be a benefit by seven of the respondents, but considered as a hindrance by one respondent:

'the structure that I had at university was not helpful when I came to develop it further in school [NQT year]. I really wanted to start again and focus it much more on the Teaching Standards but I simply haven't had the time.' (Respondent C)

All respondents had continued to use the structure provided during their NQT year, with sixty per cent of them stating that they would, time permitting, use their ePortfolio for exemplary evidence. Thus developing further the findings of Loughran and Corrigan (1995, p. 574) that students value the notion of 'presenting their views of their learning to a prospective employer' and thus emphasising the importance of ownership.

\section{Unexpected Benefits}

One aspect that emerged from the research was that the pre-service teachers increased their confidence in using technologies in their classroom through using the ePortfolios. This finding is reflected in findings by Strivens et al. (2009). Wilson, Wright and Stallworth (2003) stated that the use of the ePortfolio, may have overshadowed other aspects of their pre-service teachers' development, but this was not raised by those in this research. Indeed the pre-service teachers commented on how involvement in the project and community had helped them to share and explore the use of new technologies in the classroom developing their information technology skills and subsequently forming artefacts in their ePortfolio.

\section{Conclusion}

Two key aims were identified for this phase of the research project: to pilot the use of ePortfolios beyond teacher training, initially into the Newly Qualified Teacher (NQT) year; and to identify if an ePortfolio tool could continue to support the professional development of NQTs during their continuing teaching career. The evidence from this research project would indicate that an ePortfolio is interoperable from pre-service teaching to the NQT year, and potentially beyond with an increasing sense of self-regulation in terms of goal setting, self-evaluation and self-efficacy.

However, the functional use of ePortfolios within schools, at the time of the research, indicates that this is somewhat limited. It may be that schools in the UK are still becoming emature and that the development of ePortfolios, linked to professional development and 
lifelong learning, needs to become embedded. Also as teachers become more competent and confident with using new technologies ${ }_{2}$ and new types of continuing professional development for teachers aligns more closely with elearning, the ePortfolio may find a natural role for teachers.

The findings from this research would suggest that an ePortfolio as a space for developing professional self-identity through community needs to be embraced within higher education pedagogy and shared with pre-service teachingteachers. However, consideration needs to be given to whether the ePortfolio should be used for assessment purposes and if so how this additional layer will be embedded into the ePortfolio and balanced with the need for ownership identified in this research. It may be that in becoming a teacher through preservice training, assessment and feedback, particularly formative feedback, may provide a purpose for the ePortfolio, that is no longer required in the transition into the NQT experience. Audience may also naturally change as the assessment purpose diminishes and the need to develop within a community increases as an NQT.

Therefore, in developing an ePortfolio that can be created in pre-service training, and continued into the teaching career, careful consideration needs to be given to the ownership and the purpose. It can be simple to change structures, or create different 'pathways' through evidence for different audiences, especially utilising tagging-when ownership is clear. A structure chosen to be the most suitable for the needs of pre-service teachers, may not be the most suitable for an ePortfolio in a situated context. This is particularly the case where the focus is on reflecting on professional development needs and actions,- related to goal setting, achievement and progression, rather than on developing professional self-identify and providing evidence for assessment purposes. As schools embed ePortfolios within their systems the purpose needs to be clarified. Certainly responses from head teachers in the research indicated optimism in the development of ePortfolios with a shared vision of the embedding of ePortfolios for recording continuing professional development.

This is a new area of ePortfolio--related research in pre-service teacher education. The sample in the research was small therefore future researchers may want to encompass a larger cohort over a longer period of time, that is, beyond the NQT year. This The research provides evidence that an ePortfolio can continue to support the professional development of NQTs. It The ePortfolio provides a situated space for evidencing the development of professional identity through which it is possible to develop a sense of belonging to a community of practice. However the research indicates that schools need to provide support for NQTs in transitioning their ePortfolios to the workplace and there needs to be recognition of the changing needs of the ePortfolio owner to a more goal oriented purpose during the NQT year. The development, integration and embedding of ePortfolios in schools will be a future challenge requiring support by senior managers and teachers.

Acknowledgement: We wish to acknowledge the Training Development Agency (now Training Agency) who part-funded the final phase of this project. 


\section{References}

ABRAMI, P., and BARRETT, H., 2008. Directions for research and development on electronic portfolios. Canadian Journal of Learning and Technology/La Revue Canadienne De l'apprentissage Et De La Technologie, 31 (3).

ABRAMI, P.C., WADE, A., PILLAY, V., ASLAN, O., BURES, E.M. and BENTLEY, C., 2009. Encouraging self-regulated learning through electronic portfolios. Canadian Journal of Learning and Technology/La Revue Canadienne De l'apprentissage Et De La Technologie, 34 (3).

ALTERIO, M., 2004. Collaborative journaling as a professional development tool. Journal of further and Higher Education, 28, 321-332.

AVRAAMIDOU, L., and ZEMBAL-SAUL, C., 2003. Exploring the influence of web-based portfolio development on learning to teach elementary science. Journal of Technology and Teacher Education, 11 (3), 415-442.

BANDURA, A., 2001. Social cognitive theory: An agentic perspective. Annual Review of Psychology, 52 (1), 1-26.

BANDURA, A., 1982. Self-Efficacy Mechanism in Human Agency. American Psychologist, 37 (2), 122-147.

BARRETT, H.C., 2007. Researching electronic portfolios and learner engagement: The REFLECT initiative. Journal of Adolescent \& Adult Literacy, 50 (6), 436-449.

BARRETT, H.C., and GARRETT, N., 2009. Online personal learning environments: structuring electronic portfolios for lifelong and life-wide learning. On the Horizon, 17 (2), $142-152$.

BEAUCHAMP, C., and THOMAS, L., 2010. Reflecting on an ideal: student teachers envision a future identity. Reflective Practice, 11 (5), 631-643.

BEIJAARD, D., VERLOOP, N. and VERMUNT, J.D., 2000. Teachers' perceptions of professional identity: An exploratory study from a personal knowledge perspective. Teaching and Teacher Education, 16 (7), 749-764.

BINGIMLAS, K.A., 2009. Barriers to the successful integration of ICT in teaching and learning environments: A review of the literature. Eurasia Journal of Mathematics, Science \& Technology Education, 5 (3), 235-245.

BOGDAN, R.C., and BIKLEN, S.K., 1998. Qualitative Research for Education An Introduction to Theory and Methods. Boston: Allyn and Bacon.

BOLLIGER, D., and SHEPHERD, C., 2010. Student perceptions of ePortfolio integration in online courses. Distance Education, 31 (3), 295-314.

BOULTON, H., and HRAMIAK, A., 2012. E-flection: the development of reflective communities of learning for trainee teachers through the use of shared online web logs. 
Reflective Practice: International and Multidisciplinary Perspectives [online], , 1-13. Available at: http://dx.doi.org/10.1080/14623943.2012.670619 [Accessed 28.05.12].

CAMBRIDGE, D., 2008. Audience, integrity, and the living document: eFolio Minnesota and lifelong and lifewide learning with ePortfolios. Computers \& Education, 51 (3), 1227 1246 .

CARR, W., and KEMMIS, S., 1986. Becoming Critical. Education, Knowledge and Action Research. Lewes: Falmer.

CHALLIS, D., 2008. Towards the mature ePortfolio: Some implications for higher education. Canadian Journal of Learning and Technology/La Revue Canadienne De l'apprentissage Et De La Technologie, 31 (3).

CHATHAM-CARPENTER, A., SEAWEL, L. and RASCHIG, J., 2010. Avoiding the Pitfalls: Current Practices and Recommendations for ePortfolios in Higher Education. Journal of Educational Technology Systems, 8 (4), 437-456.

CONWAY, P.F., 2001. Anticipatory reflection while learning to teach: From a temporally truncated to a temporally distributed model of reflection in teacher education. Teaching and Teacher Education, 17 (1), 89-106.

DEWEY, J., 1933. How We Think. New York: Heath.

FALCHIKOV, N., 2005. Improving assessment through student involvement: Practical solutions for aiding learning in higher and further education. London: Routledge.

GRANBERG, C., 2010. E-portfolios in teacher education 2002-2009: the social construction of discourse, design and dissemination. European Journal of Teacher Education, 33 (3), 309322.

HAMMOND, M., CROSSON, S., FRAGKOULI, E., INGRAM, J., JOHNSTON-WILDER, P., JOHNSTON-WILDER, S., KINGSTON, Y., POPE, M.and WRAY, D. 2009. 'Why do some student teachers make very good use of ICT? An exploratory case study, Technology, Pedagogy and Education, 18 (1), 59-73.

HARTMANN, C., and CALANDRA, B., 2007. Diffusion and reinvention of ePortfolio design practices as a catalyst for teacher learning. Technology, Pedagogy and Education, 16 (1), 77-93.

HATTON, N., and SMITH, D., 1995. Reflection in teacher education: Towards definition and implementation. Teaching and Teacher Education, 11 (1), 33-49.

IMHOF, M., and PICARD, C., 2009. Views on using portfolio in teacher education. Teaching and Teacher Education, 25 (1), 149-154.

JAFARI, A., and KAUFMAN, C., 2006. Handbook of Research on ePortfolios. Information Science Reference. 
JAY, J.K., and JOHNSON, K.L., 2002. Capturing complexity: A typology of reflective practice for teacher education. Teaching and Teacher Education, 18 (1), 73-85.

JOINT INFORMATION SYSTEMS COMMITTEE (JISC), 2008. Effective Practice with $e$ Portfolios. London: Higher Education Funding Council for England.

JONES, E., 2010. Enhancing professionalism through a professional practice portfolio. Reflective Practice, 11 (5), 593-605.

JOYES, G., GRAY, L. and HARTNELL-YOUNG, E., 2010. Effective practice with eportfolios: How can the UK experience inform implementation. Australasian Journal of Educational Technology, 26 (1), 15-27.

KOLB, D., 1984. Experiential Learning. Experience as The Source of Learning and Development. New Jersey: Prentice-Hall.

LANKES, A.M.D., 1995. Electronic portfolios: A new idea in assessment. Eric Digest.ED390377, .

LAVE, J., and WENGER, E., 1991. Situated learning : Legitimate peripheral participation. Cambridge: Cambridge University Press.

LAZARUS, E., and OLIVERO, F., 2009. Videopapers as a tool for reflection on practice in initial teacher education. Technology, Pedagogy and Education, 18 (3), 255-267; 255.

LIN, B., and HSIEH, C., 2001. Web-based teaching and learner control: a research review. Computers \& Education, 37 (3-4), 377-386.

LORENZO, G., and ITTELSON, J., 2005. An overview of e-portfolios. Educause Learning Initiative, 14, 1-27.

LOUGHRAN, J., and CORRIGAN, D., 1995. Teaching Portfolios: A Strategy for Developing Learning and Teaching in Preservice Education. Teaching and Teacher Education, 11 (6), 565-577.

LOUGHRAN, J., 2002. Effective Reflective Practice: In Search of Meaning and Learning about Teaching. Journal of Teacher Education, 53 (33).

MASON, R., PEGLER, C. and WELLER, M., 2004. E-portfolios: an assessment tool for online courses. British Journal of Educational Technology, 35 (6), 717-727.

MEYER, E., ABRAMI, P.C., WADE, C.A., ASLAN, O. and DEAULT, L., 2010. Improving literacy and metacognition with electronic portfolios: Teaching and learning with ePEARL. Computers \& Education, 55 (1), 84-91.

MINOCHA, S., 2009. Role of social software tools in education: a literature review. Education Training, 51 (5/6), 353-369.

MOON, J., 1999. Reflection in Learning and Professional Development. Abingdon: RoutledgeFalmer. 
PARK, S., and LIM, J., 2006. The Impacts of reflection facilitating strategy on pre-service teachers' flow experience and achievement in E-Portfolio. TECHNOLOGY AND TEACHER EDUCATION ANNUAL, 5, 3572.

REASON, P., and BRADBURY, H., 2008. The SAGE Handbook of Action Research: Participative Inquiry and Practice. 2nd ed. London: Sage Publications.

REASON, P., and BRADBURY, H., 2006. Handbook of Action Research. London: Sage.

ROBERTS, A., 2009. Encouraging reflective practice in periods of professional workplace experience: The development of a conceptual model. Reflective Practice, 10 (5), 633-644.

ROCCO, S., 2010. Making reflection public: using interactive online discussion board to enhance student learning. Reflective Practice, 11 (3), 307-317.

SCHON, D., 1983. The Reflective Practitioner: How Professionals Think in Action. New York: Basic Books.

SEALE, J., and ABBOTT, C., 2007. Methodological Issues in Researching Online Representations: Production, Classification and Personal Web Space. International Journal of Research \& Method in Education, 30 (2), 14.

SNIDER, S.L., 2002. Exploring Technology Integration in a Field-Based Teacher Education Program: Implementation Efforts and Findings. Journal of Research on Technology in Education, 34, n3.

STENBERG, K., 2010. Identity work as a tool for promoting the professional development of student teachers. Reflective Practice, 11 (3), 331-346.

STRIVENS, J., BAUME, D., GRANT, S., OWEN, C., WARD, R. and NICOL, D., 2009. The role of e-portfolios in formative and summative assessment: Report of the JISC-funded study. Unpublished Study, Centre for Recording Achievement for JISC.Retrieved on November, 1, 2009.

STUDLER, N., and WETZEL, K., 2011.

Electronic Portfolios in Teacher Education:

Forging a Middle Ground. Journal of Research on Technology in Education, 44 (2), 162-173.

VERNAZZA, C., DURHAM, J., ELLIS, J., TEASDALE, D., COTTERILL, S., SCOTT, L., THOMASON, M., DRUMMOND, P. and MOSS, J., 2011. Introduction of an e - portfolio in clinical dentistry: staff and student views. European Journal of Dental Education, 15 (1), 3641.

WADE, A., ABRAMI, P. and SCLATER, J., 2008. An electronic portfolio to support learning. Canadian Journal of Learning and Technology/La Revue Canadienne De l'apprentissage Et De La Technologie, 31 (3).

WENGER, E., 1998. Communities of Practice. Cambridge: Cambridge University Press. 
WILSON, E.K., WRIGHT, V.H. and STALLWORTH, B.J., 2003. Secondary preservice teachers' development of electronic portfolios: An examination of perceptions. Journal of Technology and Teacher Education, 11 (4), 515-528.

WRIGHT, V.H., STALLWORTH, B.J. and RAY, B., 2002. Challenges of electronic portfolios: Student perceptions and experiences. Journal of Technology and Teacher Education, 10 (1), 49-62.

YAFFE, E., 2010. The reflective beginner: using theory and practice to facilitate reflection among newly qualified teachers. Reflective Practice, 11 (3), 381-391.

YOUNG, D., 2008. ePortfolios in Education: a cause for reflection. In: SOLSTICE 2008 Conference, Edge Hill University, 5 June.

ZELLERS, M., and MUDREY, R., 2007. Electronic Portfolios and Metacognition: A phenomenological examination of the implementation of e-Portfolios from the instructors' perspective. International Journal of Instructional Media, 34, 419-430. 